\title{
Board Characteristics, Political Connections, and Corporate Cash Holdings: The Role of Firm Size and Political Regime
}

\author{
Sabeeh Ullah ${ }^{1}$, Yasir Kamal ${ }^{2}$
}

\begin{abstract}
This paper examines the relationship of board characteristics with cash holding, and the interplay of political connections on this relationship. For this purpose, panel data of 150 non-financial firms ranging from 2001 to 2014 are used. We document that board characteristics are important predictors of a firm's cash holding in Pakistan. Theoretically, the findings mainly support agency theory. Consistent with prior studies, our empirical results show some statistical variations in large and small size sampled firms, and dictator and democratic regimes. Moreover, we investigate the interplay of political connections on the relationship of board characteristics and cash holding. Our findings support the complementary effect hypothesis.
\end{abstract}

Keywords: Board characteristics, cash holding, political connections, political regime.

\section{Introduction}

Agency theory (Jensen 1986; Stulz, 1990) suggests that massive cash holding leads to agency problem of free cash flow, because entrenched manager do not distribute massive cash holding among shareholders (Jensen, 1986; Dittmar, Mahrt-Smith, \& Servaes, 2003). Moreover, as compared to physical assets, massive cash holding can more easily be used by managers for private benefits (Chen \& Chuang, 2009). Belghitar and Khan (2013) found that any change in excess cash holding depends on a firm's corporate governance structure. Prior studies tried to linked firm's corporate governance with cash holding in international settings (Dittmar et al., 2003; Pinkowitz, Stulz, \& Williamson, 2006; Harford, Mansi, \& Maxwell, 2008). However, these studies have provided inconclusive evidence for the relationship between corporate governance and cash holding (Kuan, Li, \& Liu, 2012). This inconsistency in the results are due to different business challenges and opportunities that a firm may face across

1 PhD Scholar, SZABIST, Islamabad. Email: sabehmath@yahoo.com

2 Assistant Professor, Institute of Management Sciences, Peshawar. Email: yasir.kamal@imsciences. edu.pk

\begin{tabular}{|c|c|c|}
\hline \multicolumn{3}{|l|}{ ARTICLE HISTORY } \\
\hline 7 Dec, 2016 Submission Received & 24 Jan, 2017 & First Review \\
\hline 31 Jan, 2017 Revised Version Received & 6 Feb, 2017 & Second Review \\
\hline 13 Feb, 2017 Revised Version Received & 25 Feb, 2017 & Accepted \\
\hline
\end{tabular}


different industries and subsequently retains various levels of resources for managing these opportunities and challenges (Chen, 2008).

Empirical literature suggests that these business opportunities and challenges can also be handled by creating political connections. Political connections, allow connected firms to gain advantage from various governmental interferences, such as preferential access to government and private financing, lower tax rates, and bailout opportunities (Faccio, 2006; Claessens, Feijen, \& Laeven, 2008; Wu, Wu, Zhou, \& Wu, 2012; Goldman, Rocholl, \& So, 2013). It has also been documented that political connections becomes expensive due to rent-seeking by politician(s) (Aggarwal, Meschke, \& Wang, 2012). Boubakri, Ghoul, and Saffar (2013) reported that due to close relationship of a politically connected firm and politician(s), the firm may fulfill political goals by using firm and their resources which ultimately contradicts profit and wealth maximization objectives of the firm. Moreover, Chaney, Faccio, and Parsley (2011) argued that political connections aggravate agency problem and reduce quality of corporate governance. Boubakri et al. (2013) found that with poor corporate governance, politically connected firms hold more cash, as cash is easier to extract (Caprio, Faccio, \& McConnell, 2013). Therefore, entrenched managers use massive cash holding as a way of political extraction for pursuit of political goals (Boubakri et al., 2013). Contrary to this view, Feng and Johansson (2014) argued that due to good relationship with fellow politicians, politically connected firms have less fear of political extraction and thus hold more cash as compared to non-connected counterparts. The paper addressed these mixed issues in Pakistani context, by analyzing the relationship of Board characteristics with corporate cash holding and the moderating role of political connections and political environment in this relationship.

The paper makes several contributions to the existing literature. Firstly, the study checked the effect of Board characteristics on corporate cash holding in Pakistan. Prior researches conducted in developed and developing markets have mixed evidences (Kuan et al., 2012). It merits a mention that, due to different financial and corporate governance structures in developing and developed markets, it is imperative to investigate the corporate governance mechanisms that might affect financial decisions in developing countries (Shah, 2011; Al-Najjar, 2013; D'Espallier, Huybrechts, \& Schoubben, 2013; Masood \& Shah, 2014; Sun \& Wang, 2016). Consistent with Agency theory, we found that Board Size (BSIZE) and Board Independence (BIND) have a significant and positive effect on cash holding. However, Non Executive Directors (NXD), Executive Directors (EXD), Board Meetings (BM) and Board Diversity (BDIV) have negative influence on cash holdings.

Secondly, recent literature suggests that despite corporate governance, political connections can be used by firms as a source for creation of value, because political 
connections can provide favorable outcomes (Shen, Lin, \& Wang, 2015), and can shape corporate financial policy by reducing precautionary motives of cash (Hill, Fuller, Kelly, \& Washam, 2014). Accordingly, political connections may act as a complement for good corporate governance in terms of corporate cash holding. On the contrary, from an Agency cost perspective, politically connected firms stockpile more cash (Boubakri et al., 2013). Since liquid assets are easier to extract (Caprio et al., 2013), therefore entrenched manager use massive cash holding for political extraction and fulfillment of political goals (Boubakri et al., 2013), weakening the control functions of the board (You \& Du, 2012) and hence affects the firm's value negatively (Wu et al., 2012). Yeh, Shu, and Chiu (2013) also argued that in weak corporate governance, political connections can be used as a substitute for obtaining better firm performance. Due to these inclusive results of political connections (Jackowicz, Kozłowski, \& Mielcarz, 2014), its effect on corporate governance (Ding, Jia, Wu, \& Zhang, 2014), and the joint effect of political connections and corporate governance are rarely being studied (Shen et al., 2015). Also, as reported by (Ding et al., 2014, p. 2), "most prior studies of political connections have left the effects of these connections on corporate governance unexamined". Therefore, based on the mentioned arguments, this study for the first time offers evidence on the substitution or complementary effect of political connections on the relationship of Board characteristics with corporate cash holding in a country like Pakistan. The findings reveal that BIND, NXD, EXD, BM and BDIV support the complementary effect.

Thirdly, this study makes a comparison of research findings based on firm size. Our results revealed statistical variations in sign and significance for all the variables except BM in large and small size sampled firms. Similarly, we also found some differences in substitution and complementary effects in these subsamples. Lastly, we make a comparison of research findings based on Dictatorship and Democratic regimes in which BSIZE, BIND, EXD, BM and BDIV were found to have variations in coefficients in both regimes. Furthermore, we also found complementary effects of political connections on board variables in Democratic regime sampled firms.

The remaining part of the paper is arranged as follows. Section two discusses relevant literature and hypotheses development, section three illustrates the research design and methodology, section four provides the empirical findings, and section five provides conclusion and implications of the study.

\section{Literature Review}

In presence of perfect capital market, with zero transaction cost and no information asymmetry, firms do not need to stockpile cash (Opler, Pinkowitz, Stulz, \& Williamson, 1999; Bigelli \& Sánchez-Vidal, 2012; Steijvers \& Niskanen, 2013). Ac- 
cording to this view, in case of shortage of internal funds, external funds are raised with zero transaction cost and with no information asymmetry for investment and operating activities (Opler et al., 1999). However, in reality, market imperfection exists, due to which transaction costs and asymmetric information for raising funds matter. Earlier studies had given different explanations for firm's stockpile of cash. Most obviously, Keynes (1936) outlines three motives of firms to hold cash, namely, transactions cost motive, speculative motive and precautionary motive. Under the transaction cost motive, due to costly external financing, firms hold more cash because of the transaction cost associated with external mode of financing and the existence of asymmetric information between investor and firm (Myers \& Majluf, 1984), firms may prefer to hold more cash, especially firms with higher growth opportunities. For precautionary motive, firms may hold cash to satisfy sudden or unforeseen events without selling assets or raising external finance.

Under the speculative motive, cash can easily be used for emerging opportunities and for earning returns on investment. Jensen (1986) also argued that firm's cash holding can be used as a discretionary power over investment decisions. Instead of increasing shareholders wealth, managers may invest cash in projects that benefit their interests (Ferreira \& Vilela, 2004). Dittmar et al. (2003) found that firms in weak shareholders' protection countries hold double as much cash as compared to firms in countries with strong shareholders' rights. Furthermore, the agency cost problem that arises due to inefficient use of excess cash holding increases with more control rights (Bebchuk \& Roe, 1999), because excess control rights enable the controlling shareholder to extract benefits from the firm (Claessens, Djankov, Fan, \& Lang, 2002). According to this view, self-interested managers try to hold massive liquidity, which would be limited by the shareholder for mitigating agency conflict (Boubakri et al., 2013). In addition, a firm may establish a corporate governance mechanism to lessen agency conflict, because any surge or reduction in excess cash holdings depends on the structure of corporate governance (Belghitar \& Khan, 2013).

Based on agency theory, prior studies have tried to build the relationship between corporate governance mechanisms and cash holdings both in developing and developed markets, but the results of those studies are mixed and unable to give evidence that weak corporate governance is associated with massive cash holding (Kuan et al., 2012). Similarly, prior literature also links corporate cash holding with firm's political connections and indicates that political connections can be used as a source for firms' value. Moreover, political connections can shape corporate financial policy by reducing precautionary motives of cash (Hill et al., 2014) and benefit firms by giving easy access to external finance (Khwaja \& Mian, 2005; Claessens et al., 2008; Shen et al., 2015). Under the agency cost view, politically connected firms hold more cash as 
compared to their non-connected peers (Boubakri et al., 2013). Since liquid assets are easier to extract (Caprio et al., 2013); therefore, entrenched managers use massive cash holding as a mean of political extraction for achieving political goals (Boubakri et al., 2013). On the other hand, due to good relationship with fellow politicians, politically connected firms have less fear of political extraction and therefore hold more cash.

\subsection{Board Size (BSIZE) and Cash Holdings}

In corporate governance literature, findings of prior studies remain inconclusive about the BSIZE. For instance, researchers argued that larger BSIZE tends to be ineffective in decisions and has higher managerial cost (Al-Manaseer, Al-Hindawi, Al-Dahiyat, \& Sartawi, 2012; Pathan, Skully, \& Wickramanayake, 2007), poor corporate governance (Wasserman, 2003; Yermack, 1996) and is easier for CEO to control (Jensen, 1993). While other researchers argued that larger BSIZE tends to be more diversified in terms of background, expertise and resources (Dalton, Daily, Johnson, \& Ellstrand, 1999; Haniffa \& Hudaib, 2006), more effective in monitoring (Adams \& Mehran, 2003; Harris \& Raviv, 2008; Xie, Davidson, \& DaDalt, 2003), protecting shareholders interest (Adams \& Mehran, 2003), and developing more external linkages (Dalton et al., 1999). Due to these conflicting arguments, we hypothesize the relationship as follows:

Hypothesis 1: The relationship between BSIZE and cash holdings is negative.

\subsection{Board Independence (BIND) and Cash Holding}

Prior empirical literature for the relationship of BIND and cash holding provides mixed evidence. Yammeesri and Herath (2010) argued that it is still inconclusive that whether independent director on the board effectively monitors management and enhances corporate value or not. Based on Opler et al.'s (1999) financial hierarchy theory; BIND is positively related to cash holding, as BIND reduces agency cost of cash holding by providing better shareholder protection. On the other hand, Ozkan and Ozkan (2004) argued that due to lower information asymmetry that arises through higher BIND, firms may be able to raise funds externally, as provider of external finance requires higher BIND (Johannisson \& Huse, 2000). In this situation, there is no need to hold more cash and the relationship between BIND and cash holding is negative (Chen, 2008). Kusnadi (2011) also found similar results. However, studies conducted by (Harford et al., 2008; Kuan et al., 2012) found insignificant relationship between BIND and cash holding. Based on these empirical results, we hypothesize as:

Hypothesis 2: BIND has negatively affects corporate cash holdings. 


\subsection{Executive Directors (EXD) and Cash Holding}

In empirical literature, it is inconclusive whether adding an EXD to the corporate board entrench incumbent management teams or to enhance board effectiveness. From an Agency theory perspective, in order to maximize CEO welfare and entrenchment, influential CEOs select EXD on the board. As for their compensation, continuous employment and private benefits derived from the firm, EXD are dependent on the CEO (Fee \& Hadlock, 2004); most studies presume that EXD do not take a position in the boardroom that challenges the CEO. Agency theory also suggests that entrenched managers like to stockpile cash rather than to issue dividends to shareholders, which results in agency problem of free cash flow (Jensen \& Meckling, 1976; Dittmar et al., 2003). Based on these arguments, EXD are likely to favor stockpile of cash. On the contrary, the inclusion of EXD on the board can improve board effectiveness in decision making process, because EXD are an important source of firm's related information (Fama \& Jensen, 1983; Masulis \& Mobbs, 2011). Similarly, the inclusion of EXD enhances board's monitoring and advisory functions (Adams \& Ferreira, 2007; Harris \& Raviv, 2008), and shareholder wealth creation (Acharya, Myers, \& Rajan, 2011). Based on these arguments, we hypothesize as:

Hypothesis 3: The relationship between EXD and cash holdings is positive.

\subsection{Non Executive Directors (NXD) and Cash Holdings}

It is generally believed that the presence of NXD on the board provides better governance. Fama and Jensen (1983) argued that NXD improve monitoring and reduce the conflict of interest between managers and shareholders. In a similar vein, Jensen and Meckling (1976) argued that representation of NXD on the board control the opportunistic behavior of management, maximizing shareholders interest and reducing agency cost. Accordingly, Lee and Lee (2009) argued that the presence of NXD on the board mitigate managerial entrenchment and expropriation of firm resources. They also found that the presence of NXD is negatively related to firm's cash holding. On contrary, researchers also argued that due complex nature of firms, it is difficult for NXD to effectively monitor management (Estes, 1980). Accordingly, Lasfer (2002) indicate that large representation of NXD on the board results in high remuneration and coordination costs and delayed decision making in high growth firms. In addition, Sethi, Cunningham, and, Swanson (1979) argued that larger representation of NXD on the board may lead to ineffective board monitoring and create conflict of interest between the board and top management. From the study of SMEs' in UK setting, (Belghitar \& Khan, 2013) found an insignificant relation between representation of NXD and firm's cash holding and argued that the mechanisms of NXD on the board are ineffective to mitigate free cash flow problems. Based on the arguments 
mentioned, we hypothesize as:

Hypothesis 4: There is a negative relationship between NXD and cash holding.

\subsection{Board Meetings (BM) and Cash Holdings}

Aldamen, Duncan, Kelly, McNamara, and Nagel (2012) argued that board effectiveness can be increased by having frequent BM. Similarly, Zhang, Zhou, and Zhou (2007) argued that meeting frequency affects board effectiveness which in turn affects the quality of internal control. Additionally, with more frequent meetings, the boards have time to set strategies (Vafeas, 1999), and to work for the best interest of shareholders (Lipton \& Lorsch, 1992). Alternatively, studies also documented that more frequent BM are not useful to enhance board effectiveness and control. Vafeas (1999) documented that frequent BM are costly for the firm because they consume management time and cause expenses in the form of travel and allowances. In addition, due to more frequent meetings, NXD are left with limited time for effectively monitoring management and sharing fruitful ideas among themselves (Jensen, 1993; Vafeas, 1999), which reduces board monitoring (Lipton \& Lorsch, 1992). Based on these premises, we set our hypothesis as:

Hypothesis 5: The relationship between frequency of BM and cash holdings is negative.

\subsection{Board Diversity (BDIV) and Cash Holdings}

In prior literature, the relationship between BDIV and cash holding is inconclusive. For this, we formalize two alternative objective functions for board diversity, that is the precautionary and Agency cost motives of cash holding. From an agency cost perspective, the inclusion of female directors on the board benefits an organization by enhancing board effectiveness (Adams \& Ferreira, 2009), and monitoring quality (Campbell \& Minguez-Vera, 2008). Thus, BDIV influences the effectiveness of the board and gives benefits to shareholders. As an effective board reduces the opportunistic behavior of the management by reducing agency cost of free cash flow (Boubaker, Derouiche, \& Nguyen, 2013), and reduce the possibility of expropriation of firm resources (Hamzah \& Zulkafli, 2014). Alternatively, from precautionary motive perspective, prior researchers documented that females are more risk averse (Levin, Snyder, \& Chapman, 1988), and less confident in decisions (Dowling \& Aribi, 2013) as compared to their male counterpart. Loukil and Yousfi (2016) argued that boards that have female directors do not make risky and challenging investments. Accordingly, Smith, Smith, and Verner (2006) report that in a more competitive environment, BDIV may experience more conflicts which in turn reduces the pace of decision making process despite the demand of quick response to the market shocks. Summing 
up, due to risk averse and less confident nature of females, firms with gender diverse boards hold more cash (Loukil \& Yousfi, 2016; Van Uytbergen \& Schoubben, 2015). Therefore, we hypothesize as:

Hypothesis 6: The relationship between BDIV and cash holdings is positive.

\subsection{Political Connections, Corporate Governance and Cash Holding}

From the literature, it is evident that firms with good corporate governance do not expropriate cash and will protect the interest of minority shareholders. As Good corporate governance can benefit firms by giving favorable benefits (Shen et al., 2015; Yeh et al., 2013) and hence hold less cash (Al-Najjar, 2014; Chen, 2008). On the other hand, politically connected firms may exhibit the same preferential treatments (Khwaja \& Mian, 2005; Claessens et al., 2008; Shen et al., 2015) and hold less cash. Accordingly, political connections may act as a complement for good corporate governance in terms of corporate cash holding. Therefore, we hypothesize as:

Hypothesis 7a: (Complementary effect): Considering both Strong (Weak) Board characteristics and Political connections reduce (enhance) corporate cash holdings.

The two concepts may become substitute when taking it under the view of agency problems, as liquid assets are easier to extract (Caprio et al., 2013), therefore, entrenched managers use massive cash holding as a mean of political extraction for fulfilling political agendas. In addition, due to political pressure and intervention, the role of monitoring and controlling management is weak in these firms. With weak corporate governance, self-interested managers may pursue their own benefits by holding massive cash. Therefore, we hypothesize as:

Hypothesis 7a: (Substitution effect): Considering both Strong (Weak) Board characteristics and Political connections enhance (reduce) corporate cash holding.

\section{Methodology}

The sampled firms that were used to study the relation among Board characteristics, cash holdings, and the interplay of political connections were drawn from companies listed on the Pakistan Stock Exchange (PSX), Pakistan. Fourteen years panel data of 150 non-financial firms ranging from 2001 to 2014 has been employed which were further divided into sub samples based on large and small size firms, dictator regime (2001-2007) and democratic regime (2008-2014). Additionally, the variables used in this paper and their measurements are provided in Table 1.

For of achieving the required objectives, the study first linked the board charac- 
Table 1: List of all Variables and their Definitions

\begin{tabular}{|c|c|c|c|}
\hline Variables & Acronyms & Definition & Source \\
\hline Board Size & BSIZE & $\begin{array}{l}\text { Total size of the board at the end of financial } \\
\text { year. }\end{array}$ & $\begin{array}{l}\text { Annual } \\
\text { Report }\end{array}$ \\
\hline $\begin{array}{l}\text { Board Indepen- } \\
\text { dence }\end{array}$ & BIND & $\begin{array}{l}\text { Proportion of IND to total directors on the } \\
\text { board. }\end{array}$ & $\begin{array}{l}\text { Annual } \\
\text { Report }\end{array}$ \\
\hline Board meetings & $\mathrm{BM}$ & Number of BM held during a financial year. & $\begin{array}{l}\text { Annual } \\
\text { Report }\end{array}$ \\
\hline $\begin{array}{l}\text { Non-executive } \\
\text { Directors }\end{array}$ & NXD & Number of NXD on the board. & $\begin{array}{l}\text { Annual } \\
\text { Report }\end{array}$ \\
\hline $\begin{array}{l}\text { Executive Direc- } \\
\text { tors }\end{array}$ & EXD & Number of EXD on the board. & $\begin{array}{l}\text { Annual } \\
\text { Report }\end{array}$ \\
\hline Board Diversity & BDIV & $\begin{array}{l}\text { A dummy variable which has a value " } 1 \text { " if a } \\
\text { female director is present on the board " } 0 \text { " } \\
\text { otherwise. }\end{array}$ & $\begin{array}{l}\text { Annual } \\
\text { Report }\end{array}$ \\
\hline Cash holding & $\mathrm{CASH}$ & $\begin{array}{l}\text { Cash and near to cash to total assets minus cash } \\
\text { and near to cash. }\end{array}$ & SBP-BSA \\
\hline $\begin{array}{l}\text { Political Connec- } \\
\text { tions Dummy }\end{array}$ & PC & $\begin{array}{l}\text { A dummy variable which has a value " } 1 \text { " if a firm } \\
\text { is politically connected and "0" otherwise. }\end{array}$ & $\begin{array}{l}\text { Research- } \\
\text { er's Manual } \\
\text { Calculation } \\
\end{array}$ \\
\hline Firm Size & FSIZE & The natural logarithm of total assets. & SBP-BSA \\
\hline Leverage & LEV & $\begin{array}{l}\text { Current debt plus non-current debts to total } \\
\text { assets. }\end{array}$ & SBP-BSA \\
\hline Dividend Dummy & DIV & $\begin{array}{l}\text { A dummy variable that has a value " } 1 \text { " if the com- } \\
\text { pany pay dividend in the year and "0" otherwise. }\end{array}$ & SBP-BSA \\
\hline Cash Flow & $\mathrm{CF}$ & $\begin{array}{l}\text { Net earnings plus depreciation and amortization } \\
\text { to total assets. }\end{array}$ & SBP-BSA \\
\hline $\begin{array}{l}\text { Growth Opportu- } \\
\text { nities }\end{array}$ & GOPP & Percentage change in yearly sale. & SBP-BSA \\
\hline $\begin{array}{l}\text { Market to book } \\
\text { value }\end{array}$ & MTB & $\begin{array}{l}\text { The market value per share to book value per } \\
\text { share. }\end{array}$ & SBP-BSA \\
\hline $\begin{array}{l}\text { Capital Expen- } \\
\text { diture }\end{array}$ & CAPEX & $\begin{array}{l}\text { Capital expenditures (i.e., change in fixed assets } \\
\text { plus depreciation) to total assets }\end{array}$ & SBP-BSA \\
\hline Asset tangibility & AT & Tangible fixed assets to total assets. & SBP-BSA \\
\hline $\begin{array}{c}\text { Net working } \\
\text { capital }\end{array}$ & NWC & $\begin{array}{l}\text { Net working capital minus cash to total assets } \\
\text { minus cash. }\end{array}$ & SBP-BSA \\
\hline $\begin{array}{l}\text { Cash flow vola- } \\
\text { tility }\end{array}$ & $\mathrm{CFV}$ & Standard deviation of cash flow to total assets. & SBP-BSA \\
\hline
\end{tabular}


teristics with corporate cash holdings. Secondly, for substitution and complementary effect, the study checked the interplay of political connections on the relationship of board characteristics and cash holding. Thirdly, we compared the above relationships on the basis of large and small size firms, dictator regime (2001-2007) and democratic regime (2008-2014).

As it is evident from empirical corporate finance research that the causal effects of financial decisions have serious issues of endogeniety due to difficulty in finding exogenous variables or natural experiments for the relationship being examined (Wintoki, Linck, \& Netter, 2012). Roberts and Whited (2012) argued that "endogeniety leads to biased and inconsistent parameter estimates that make reliable inferences virtually impossible."

More specifically, the relationship of corporate governance and cash holding is simultaneous (Chen, 2008; Jackowicz et al., 2014; Kuan, Li, \& Chu, 2011; Kuan et al., 2012), as many corporate decisions are determined endogenously, either contemporaneously or simultaneously (Chen, 2008). Therefore, modeling these relationships will create problems if no appropriate treatment is made for endogeniety (Kuan et al., 2011). To overcome this problem, this paper used dynamic panel data models (System GMM) for each objective.

\section{Analysis and Results}

\subsection{Summary Statistics and Correlation Matrix}

Table 2 reports the summary statistics of the study variables. Our typical board size has a mean of about 8 in the whole sample. This result is consistent with (Bokpin, Isshaq, \& Aboagye-Otchere, 2011; Zhang et al., 2007). For the whole sample, 47\% board members are independent directors. This result is slightly higher than the findings of (Chen \& Chuang, 2009) that is $42.6 \%$. The mean of EXD and NXD is about 3 and 5 respectively. It indicates that substantial number of NXD (on average $62.5 \%$ ) is present on Pakistani firm's board. This result is slightly higher than the result found by (Bhagat \& Black, 2002) in the USA (60\%). The mean of BM is 5.4 in the whole sample, which is less than the mean value 6.32 of (Jackling \& Johl, 2009; Zhang et al., 2007). For the whole sample the mean value of BDIV is 0.38 indicating that $38 \%$ of the firms have 1 female director on the board. Furthermore, Pakistani firms hold on average $4.7 \%$ of total assets as cash. Dittmar et al. (2003); Saeed, Belghitar, and Clark (2014) also reported that Pakistani firms on average hold 5.6\% and $5.3 \%$ of cash respectively.

Table 3 documented the results of Pearson's correlation of all independent vari- 


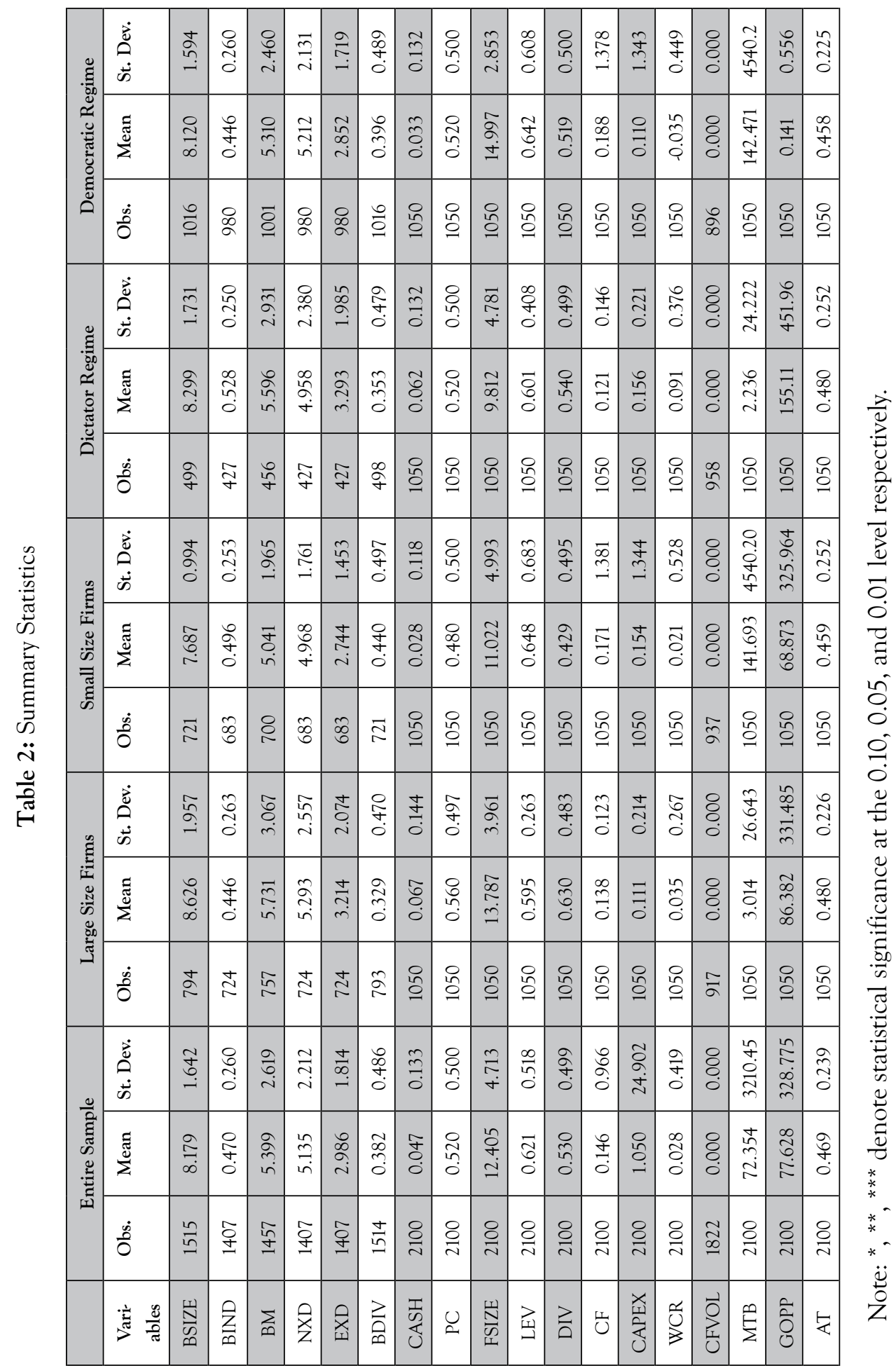




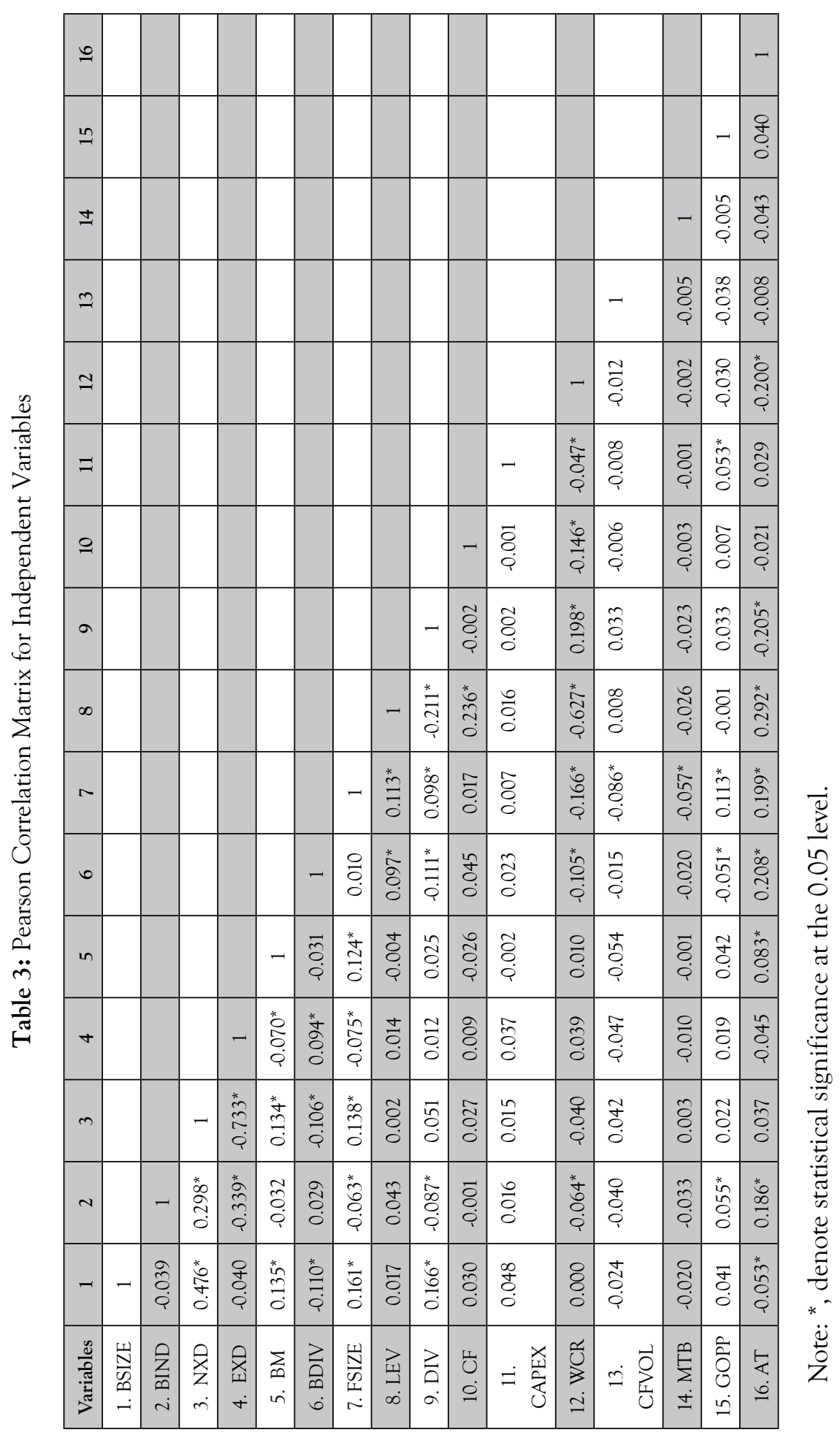


ables. Gujarati (2009) reported that when correlation exceeds 0.80 then it creates problem of multicollinearity. In our case the highest correlation exists between EXD and NED which is 0.73 . This shows that our data is free from multicollinearity problem.

\subsection{Regression Results}

\subsubsection{Effect of Board Characteristics on Cash Holdings}

Table 4 reports the results of the effect of Board characteristics on cash holdings. We employed dynamic panel data models (System GMM). The p-values of Sargan test and AR (2) were insignificant in the full sample and subsamples, suggesting that the instruments used in the model are valid and the data free from serial correlation problem. The coefficients of BSIZE and BIND are positive and statistically significant in the full sample. This shows that firms having larger BSIZE and BIND stockpile more cash. This result is in line with (Lee \& Lee, 2009). Furthermore, we found that NED, EXD, BM and BDIV negatively affect cash holding, showing that increasing NED, EXD, BM and BDIV reduces firm's cash holdings. Consistent with the view that NED and EXD have greater knowledge of firm operations, effective monitoring, and reduce the agency cost of free cash flows (Jensen \& Meckling, 1976; Fama \& Jensen, 1983). Similarly, the negative sign of BM follows the notion that more frequent BM increase the effectiveness of board monitoring (Aldamen et al., 2012). Lastly, the negative results of BDIV in relation to cash holding is consistent with the notion that BDIV influences the effectiveness of the board and gives benefits to shareholders.

Regarding large and small size sampled firms, we found some statistical variations in signs of the coefficients of BSIZE, BIND, NXD, EXD and BDIV. In large sampled firms, the coefficient of BSIZE is positive in relation to cash holding indicating that firm's cash holding increases with increase in BSIZE. Consistent with the notion that larger board have aversive attitude towards monitoring (Hermalin \& Weisbach, 2003), increase CEO entrenchment (Jensen, 1993) and resultantly firms hold more cash. Similarly, an increase in BIND, NXD, EXD, BM and BDIV reduces firm's cash holding. This result supports the notion that increasing BIND, EXD, NED, BM and BDIV enhances board monitoring and effectiveness, which resultantly reduces firms cash holding (Adams \& Ferreira, 2007; Aldamen et al., 2012; Chen, 2008; Conger, Finegold, \& Lawler, 1998; Harris \& Raviv, 2008; Kusnadi, 2011; Lee \& Lee, 2009; Raheja, 2005). Moreover, for smaller firms, we found that BIND, NED, EXD and BDIV positively affect cash holding, whereas BSIZE and BM negatively influence cash holding.

The positive sign of BIND, NED, EXD and BDIV follows the findings of (Dittmar et al., 2003; Jensen, 1986; Lasfer, 2002; Loukil \& Yousfi, 2013; Opler et al., 1999; 
Van Uytbergen \& Schoubben, 2015). Similarly, the negative sign of BSIZE and BM are in line with the notion that larger BSIZE and more frequent BM enhance board monitoring and effectiveness (Adams \& Ferreira, 2007; Adams \& Mehran, 2003; Aldamen et al., 2012; Zhang et al., 2007), which resultantly reduces firm's cash holding.

Table 4 also reports the results of subsample based on dictator and democratic regimes. In both regimes, we found some variations in sign and significance. The Coefficient of BSIZE and BIND is significantly positive in democratic regime, but insignificant in dictator regime. This shows that firms with larger BSIZE and BIND hold more cash in a democratic regime, which supports the findings of (Chen \& Chuang, 2009) and (Opler et al., 1999) respectively. Similarly, the coefficient of NED is negatively significant in both regimes, whereas the coefficient of EXD is only negative and statistically significant in democratic regime. It indicates that firms reduce their cash level when their board has a larger number of NED and EXD. This result supports the notion that representation of large number of NED and EXD on the board leads to more effectiveness in decision making process (Jensen \& Meckling, 1976; Fama \& Jensen, 1983). Lastly, the positive and significant coefficient of BDIV in dictator regime reveals that the presence of female directors on the board enhances cash level in dictator regime. This result is in line with (Loukil \& Yousfi, 2013; Van Uytbergen \& Schoubben, 2015) who argued that firms with gender diverse board holds more cash.

4.2.2 Interplay of Political Connections on the Relationship of Board Characteristics and Cash holdings

Table 5 illustrates the empirical results of the interplay of Political Connections on the relationship of Board characteristics and Cash holdings for the full sample and subsamples. Here the main variable of interest is the interaction between internal corporate governance mechanisms and political connections dummy.

For full sample, significantly positive coefficients of BIND ( $t-1)$ * $\mathrm{PC}$ indicates that connected firms with BIND stockpile more cash than non connected counterparts. This supports our complementary effect hypothesis and the argument of (Estes, 1980) that due to the complex nature of firms, it is difficult for independent directors to effectively monitor management. The coefficients of NXD ( $t-1)$ * $\mathrm{PC}, \operatorname{EXD}(\mathrm{t}-1){ }^{*} \mathrm{PC}$, $\mathrm{BM}(\mathrm{t}-1){ }^{*} \mathrm{PC}$ and $\mathrm{BDIV}(\mathrm{t}-1){ }^{*} \mathrm{PC}$ are negative and statistically significant in relation to cash holding. It implies that politically connected firms with larger number of NXD and EXD, BM and BDIV are more inclined to hold less cash reserve as compared to those firms having no political connections. These results support our complementary effect hypothesis and findings of (Aldamen et al., 2012). 
Table 4: Effect of Board Characteristics on Corporate Cash holdings

\begin{tabular}{|c|c|c|c|c|c|}
\hline & \multirow[t]{2}{*}{ Full Sample } & \multicolumn{2}{|c|}{ Size Effect } & \multicolumn{2}{|c|}{ Regime Effect } \\
\hline & & Large Size & Small Size & $\begin{array}{l}\text { Dictator } \\
\text { Regime }\end{array}$ & $\begin{array}{c}\text { Democratic } \\
\text { Regime }\end{array}$ \\
\hline Variables & Coeff. & Coeff. & Coeff. & Coeff. & Coeff. \\
\hline CONSTANT & $-0.097^{* * *}$ & $0.192^{* * *}$ & $0.383^{* * *}$ & $0.559^{* *}$ & $-0.459^{* * *}$ \\
\hline $\mathrm{CASH}(\mathrm{t}-1)$ & $0.439^{* * *}$ & $0.219^{* * *}$ & $0.657^{* * *}$ & $0.418^{* * *}$ & $0.487^{* * *}$ \\
\hline $\operatorname{BSIZE}(\mathrm{t}-1)$ & $0.181^{* * *}$ & $0.229^{* * *}$ & $-0.279^{* * *}$ & -0.104 & $0.281^{* * *}$ \\
\hline $\operatorname{BIND}(t-1)$ & $0.047^{* * *}$ & $-0.059^{* * *}$ & $0.102^{* * *}$ & 0.100 & $0.062^{* * *}$ \\
\hline $\operatorname{NXD}(t-1)$ & $-0.084^{* * *}$ & $-0.125^{* * *}$ & $0.065^{* * *}$ & $-0.110^{*}$ & $-0.096^{* * *}$ \\
\hline $\operatorname{EXD}(t-1)$ & $-0.017^{* * *}$ & $-0.047^{* * *}$ & $0.053^{* * *}$ & -0.060 & $-0.052^{* * *}$ \\
\hline $\mathrm{BM}(\mathrm{t}-1)$ & $-0.030^{* * *}$ & $-0.015^{* * *}$ & $-0.043^{* * *}$ & -0.014 & -0.007 \\
\hline $\operatorname{BDIV}(\mathrm{t}-1)$ & $-0.030 * * *$ & $-0.090 * * *$ & $0.022^{* * *}$ & $0.050^{* *}$ & -0.009 \\
\hline FSIZE & $0.001^{* * *}$ & $-0.013^{* * *}$ & $0.002^{* * *}$ & 0.001 & $0.018^{* * *}$ \\
\hline LEV & $-0.072^{* * *}$ & $-0.096^{* * *}$ & $-0.013^{* * *}$ & $0.189^{* * *}$ & $-0.250^{* * *}$ \\
\hline DIV & $0.025^{* * *}$ & $0.030^{* * *}$ & $0.009^{* * *}$ & -0.017 & 0.006 \\
\hline $\mathrm{CF}$ & $0.002^{* * *}$ & $0.482^{* * *}$ & $0.001^{* * *}$ & 0.022 & $0.001^{*}$ \\
\hline CAPEX & $0.000^{* * *}$ & $0.000^{* * *}$ & 0.000 & 0.000 & -0.009 \\
\hline WCR & $-0.117^{* * *}$ & $-0.266^{* * *}$ & $-0.017^{* * *}$ & $-0.048^{* *}$ & $-0.349^{* * *}$ \\
\hline CFVOL & -6.603 & 115.23 & 38.681 & -89.80 & 55.672 \\
\hline MTB & $0.000^{* * *}$ & $0.000^{* * *}$ & $0.000^{* * *}$ & 0.000 & 0.000 \\
\hline GOPP & $0.000^{* * *}$ & $0.000^{* * *}$ & $0.000^{* * *}$ & 0.000 & 0.004 \\
\hline AT & $-0.131^{* * *}$ & $-0.289^{* * *}$ & $0.040^{* * *}$ & $-0.463^{* * *}$ & $-0.121^{* *}$ \\
\hline $\begin{array}{l}\text { Wald test } \\
\text { (P-Value) }\end{array}$ & 0.000 & 0.000 & 0.000 & 0.000 & 0.000 \\
\hline $\begin{array}{c}\text { Sargan } \\
\text { test(P-Value) }\end{array}$ & 0.223 & 0.993 & 0.998 & 0.527 & 0.240 \\
\hline $\begin{array}{l}\text { AR(2) test } \\
\text { (P-Value) }\end{array}$ & 0.069 & 0.302 & 0.675 & 0.525 & 0.353 \\
\hline Observations & 1040 & 530 & 510 & 266 & 671 \\
\hline
\end{tabular}

Note: ${ }^{*},{ }^{* *},{ }^{* *}$ denote statistical significance at the $0.10,0.05$, and 0.01 level respectively.

$\operatorname{Cash}_{i t}=\alpha+\lambda \operatorname{Cash}_{i t-1}+\beta_{1}$ BSIZE $_{i t-1}+\beta_{2}$ BIND $_{i t-1}+\beta_{3} E X D_{i t-1}+\beta_{4} N X D_{i t-1}+\beta_{5} B M_{i t-1}$ $+\beta_{6} B D I V_{i t-1}+\sum_{n} \gamma_{n}$ ControlVariables $_{n i t}+\varepsilon_{i t}$ 
For large and small size sampled firms, the coefficients of BSIZE (t-1) * PC and $\mathrm{BM}(\mathrm{t}-1)$ * $\mathrm{PC}$ are positive and statistically significant with cash holdings in large size firms but insignificant in small size firms. This shows that with large BSIZE and more frequent BM, large size connected firms holds more cash as compared to nonconnected counterparts. These results support our complementary effect hypothesis. Similarly, the coefficient of NXD (t-1) * PC is negative and statistically significant with cash holding in both the sampled firms whereas the coefficient of EXD $(t-1)$ * $\mathrm{PC}$ is negative in large size firms. It indicates that connected firms with larger number of EXD and NED hold less cash. These results support our complementary effect hypothesis in large size sampled firms and substitution effect hypothesis in small size sampled firms. Furthermore, BIND ( $t-1) * \mathrm{PC}$ is positive and significantly affects cash holding in small size firms, which is in line with our complementary effect hypothesis. Lastly, BDIV ( $t-1){ }^{*} \mathrm{PC}$ is positively related to cash holding in small size sampled firms showing that small size politically connected firms with BDIV stockpile more cash. Consistent with the findings of (Loukil \& Yousfi, 2013; Van Uytbergen $\&$ Schoubben, 2015).

Table 5 also reports the results based on dictator and democratic regime. The coefficient of BSIZE (t-1) * PC, BIND (t-1) * PC are significantly positively related with cash holdings in democratic regimes. It indicates that connected firms with larger BSIZE and BIND hold massive cash. These results support the complementary effect hypothesis and the notion that firms cash holding increases with the increase in BSIZE (Lee \& Lee, 2009; Chen \& Chuang, 2009; Bokpin et al., 2011) and board independence (Opler et al., 1999). The coefficients of EXD (t-1) * PC and NXD (t-1) * PC with cash holding are significantly negative in democratic regimes. This support the complementary effect hypothesis and the notion that considering both effective corporate governance and political connection may exhibit the same financial benefits (Shen et al., 2015) which leads to lower cash level.

Table 5: Interplay of Political Connections on the Relationship of Board Characteristics and Corporate Cash Holdings

\begin{tabular}{|c|c|c|c|c|c|}
\hline & Full Sample & \multicolumn{2}{|c|}{ Size Effect } & \multicolumn{2}{c|}{ Regimes Effect } \\
\hline & & Large Size & Small Size & $\begin{array}{c}\text { Dictator } \\
\text { Regime }\end{array}$ & $\begin{array}{c}\text { Democratic } \\
\text { Regime }\end{array}$ \\
\hline Variables & Coeff. & Coeff. & Coeff. & Coeff. & Coeff. \\
\hline CONSTANT & $0.120^{* * *}$ & $0.352^{* * *}$ & $-0.029^{* *}$ & $0.174^{* * *}$ & 0.006 \\
\hline CASH(t-1) & $0.382^{* * *}$ & $0.194^{* * *}$ & 0.643 & $0.451^{* * *}$ & $0.363^{* * *}$ \\
\hline BSIZE(t-1) & $0.163^{* * *}$ & $0.102^{* * *}$ & $-0.311^{* * *}$ & 0.023 & $0.208^{* * *}$ \\
\hline BIND(t-1) & $0.018^{* * *}$ & $-0.064^{* * *}$ & $0.065^{* * *}$ & 0.002 & $0.027^{* * *}$ \\
\hline $\mathrm{NXD}(\mathrm{t}-1)$ & $-0.092^{* * *}$ & $-0.093^{* * *}$ & $0.071^{* * *}$ & -0.083 & $-0.076^{* * *}$ \\
\hline
\end{tabular}




\begin{tabular}{|c|c|c|c|c|c|}
\hline $\operatorname{EXD}(t-1)$ & $-0.052^{* * *}$ & $-0.048^{* * *}$ & $0.044^{* * *}$ & -0.045 & $-0.044^{* * *}$ \\
\hline $\mathrm{BM}(\mathrm{t}-1)$ & $-0.008^{* * *}$ & $0.010^{*}$ & $-0.037^{* * *}$ & -0.023 & -0.006 \\
\hline $\operatorname{BDIV}(t-1)$ & $-0.009^{* *}$ & $-0.082^{* * *}$ & $0.022^{* * *}$ & $0.042^{* * *}$ & -0.009 \\
\hline PC & $-0.438^{* * *}$ & $0.240^{* * *}$ & $-0.044^{* * *}$ & 0.059 & $-0.530^{* * *}$ \\
\hline BSIZE $(t-1) *$ PC & -0.021 & $0.380^{* * *}$ & -0.029 & 0.115 & $0.332^{* *}$ \\
\hline $\operatorname{BIND}(t-1) * P C$ & $0.020^{*}$ & 0.006 & $0.041^{* * *}$ & 0.162 & $0.084^{* * *}$ \\
\hline $\mathrm{NXD}(\mathrm{t}-1) * \mathrm{PC}$ & $-0.056^{* * *}$ & $-0.149^{* * *}$ & $-0.094^{* * *}$ & -0.139 & $-0.088^{* *}$ \\
\hline $\operatorname{EXD}(t-1) * P C$ & $-0.044^{* * *}$ & $-0.096^{* * *}$ & 0.011 & -0.068 & $-0.072^{* *}$ \\
\hline $\mathrm{BM}(\mathrm{t}-1) * \mathrm{PC}$ & $-0.040 * * *$ & $0.023^{* *}$ & 0.010 & -0.047 & 0.006 \\
\hline $\operatorname{BDIV}(\mathrm{t}-1) * \mathrm{PC}$ & $-0.096^{* * *}$ & -0.015 & $0.059^{* * *}$ & -0.022 & -0.036 \\
\hline FSIZE & $-0.001^{* *}$ & $-0.017^{* * *}$ & $0.002^{* * *}$ & 0.001 & $0.014^{* * *}$ \\
\hline LEV & $-0.075^{* * *}$ & $-0.035^{* *}$ & $-0.018^{* * *}$ & $0.143^{* *}$ & $-0.248^{* * *}$ \\
\hline DIV & $0.024^{* * *}$ & $0.023^{* * *}$ & $0.009^{* * *}$ & -0.007 & 0.002 \\
\hline $\mathrm{CF}$ & $0.039^{* * *}$ & $0.520^{* * *}$ & 0.004 & 0.004 & -0.018 \\
\hline CAPEX & $-0.038^{* * *}$ & $-0.029^{* * *}$ & -0.003 & $-0.099^{* * *}$ & 0.019 \\
\hline WCR & $-0.123^{* * *}$ & $-0.240 * * *$ & $-0.024^{* * *}$ & $-0.066^{* * *}$ & $-0.353^{* * *}$ \\
\hline CFVOL & -6.413 & -77.29 & -21.18 & $-161.2^{*}$ & 56.776 \\
\hline MTB & $0.000^{* * *}$ & $0.000^{* * *}$ & $0.000^{* * *}$ & 0.000 & $0.000^{*}$ \\
\hline GOPP & $0.000^{* * *}$ & $0.000^{* * *}$ & $0.000^{* * *}$ & $0.000^{* * *}$ & 0.003 \\
\hline AT & $-0.099^{* * *}$ & $-0.215^{* * *}$ & $0.018^{* * *}$ & -0.427 & $-0.115^{* *}$ \\
\hline Wald test (P-Value) & 0.000 & 0.000 & & 0.000 & \\
\hline Sargan test(P-Value) & 0.208 & 0.995 & & 0.411 & \\
\hline $\mathrm{AR}(2)$ test (P-Value) & 0.054 & 0.457 & & 0.629 & \\
\hline Observations & 1040 & 530 & & 266 & \\
\hline
\end{tabular}

Note: ${ }^{*},{ }^{* *},{ }^{* * *}$ denote statistical significance at the $0.10,0.05$, and 0.01 level respectively.

$$
\begin{aligned}
& \operatorname{Cash}_{i t}=\alpha+\lambda \operatorname{CaSh}_{i t-1}+\beta_{1} \text { BSIZE }_{i t-1}+\beta_{2} \text { BIND }_{i t-1}+\beta_{3} E X D_{i t-1}+\beta_{4} N X D_{i t-1}+\beta_{5} B M_{i t-1} \\
& +\beta_{6} B D I V_{i t-1}+\beta_{7} P C_{i t}+\beta_{8} B S I Z E_{i t-1} \times P C_{i t}+\beta_{9} B I N D_{i t-1} \times P C_{i t}+\beta_{10} E X D_{i t-1} \times P C_{i t} \\
& +\beta_{11} N X D_{i t-1} \times P C_{i t}+\beta_{12} B M_{i t-1} \times P C_{i t}+\beta_{13} B D I V_{i t-1} \times P C_{i t}+\sum_{n} \gamma_{n} \text { ControlVariables }_{n i t}+\varepsilon_{i t}
\end{aligned}
$$

\section{Conclusion and Implications}

This study examines the role of Board characteristics in relation to cash holding, and the interplay of political connections on this relationship. We documented that BSIZE and BIND positively affect cash holding whereas NXD, EXD, BM and BDIV negatively influence cash holding. Consistent with the prior studies, this study documented that Board characteristics are important predictors of firm's cash holding for firms listed in Pakistani stock markets. Theoretically, the findings from this study mainly support the Agency theory. This study further investigates whether the effect of board characteristics on cash holding varies with firm size and political environment (Dictator and Democratic regime). Consistent with prior empirical studies, our results 
show some statistical variations in both large and small size sampled firms, and dictator and democratic regime sampled firms. For the interplay of political connections, the study proposes two alternative hypotheses for the effects that political connections have on board variables, namely complementary and substitution effect hypotheses. Our results recommend complementary effect hypothesis. Furthermore, the study also found some differences in these effects, when moving from large to small size sampled firms and Dictator to Democratic regime sampled firms.

The findings from this study also provide support to policy makers to make improvements in existing corporate governance practices and in helping the development of proper corporate culture in Pakistan. As has been observed, the differences in empirical results of large and small size firms suggest that the effect of corporate governance on firm cash holdings may not necessarily be the same. Therefore, it is deemed important for policy makers to consider the size of the firm when establishing rules or corporate governance codes. Due to importance of the effect of political connections, policy makers should establish proper regulatory mechanisms to effectively monitor firm's political connections, and reduce the possibility of executives' rent-seeking through institutional development.

\section{References}

Acharya, V. V., Myers, S. C., \& Rajan, R. G. (2011). The internal governance of firms. The Journal of Finance, 66(3), 689-720.

Adams, R. B., \& Ferreira, D. (2007). A theory of friendly boards. The Journal of Finance, 62(1), 217-250.

Adams, R. B., \& Ferreira, D. (2009). Women in the boardroom and their impact on governance and performance. Journal of Financial Economics, 94(2), 291-309.

Adams, R. B., \& Mehran, H. (2003). Is corporate governance different for bank holding companies? Available at SSRN 387561.

Aggarwal, R. K., Meschke, F., \& Wang, T. (2012). Corporate political contributions: Investments or agency. Available at: ssrn.com/abstract $=972670$

Al-Manaseer, M., Al-Hindawi, R. M., Al-Dahiyat, M. A., \& Sartawi, I. I. (2012). The impact of corporate governance on the performance of Jordanian banks. European Journal of Scientific Research, 67(3), 349-359.

Al-Najjar, B. (2013). The financial determinants of corporate cash holdings: Evidence from some emerging markets. International Business Review, 22(1), 77-88.

Al-Najjar, B. (2014). The Effect of Governance Mechanisms on Small and Medium-Sized Enterprise Cash Holdings: Evidence from the United Kingdom. Journal of Small Business Management, n/a-n/a. 
doi: $10.1111 /$ jsbm. 12062

Aldamen, H., Duncan, K., Kelly, S., McNamara, R., \& Nagel, S. (2012). Audit committee characteristics and firm performance during the global financial crisis. Accounting $\mathcal{E}$ Finance, 52(4), 971-1000.

Bebchuk, L. A., \& Roe, M. J. (1999). A theory of path dependence in corporate ownership and governance. Stanford Law Review, 52, 127-170.

Belghitar, Y., \& Khan, J. (2013). Governance mechanisms, investment opportunity set and SMEs cash holdings. Small Business Economics, 40(1), 59-72.

Bhagat, S., \& Black, B. S. (2002). The non-correlation between board independence and long-term firm performance. As published in Journal of Corporation Law, 27, 231-273.

Bigelli, M., \& Sánchez-Vidal, J. (2012). Cash holdings in private firms. Journal of Banking $\mathcal{G}$ Finance, 36(1), 26-35.

Bokpin, G. A., Isshaq, Z., \& Aboagye-Otchere, F. (2011). Ownership structure, corporate governance and corporate liquidity policy: Evidence from the Ghana Stock Exchange. Journal of Financial Economic Policy, 3(3), 262-279.

Boubaker, S., Derouiche, I., \& Nguyen, D. (2013). Does the board of directors affect cash holdings? A study of French listed firms. Journal of Management $\mathcal{E}$ Governance, 1-30.

Boubakri, N., Ghoul, S. E., \& Saffar, W. (2013). Cash holdings of politically connected firms. Journal of Multinational Financial Management, 23(4), 338-355.

Campbell, K., \& Minguez-Vera, A. (2008). Gender diversity in the boardroom and firm financial performance. Journal of Business Ethics, 83(3), 435-451.

Caprio, L., Faccio, M., \& McConnell, J. J. (2013). Sheltering corporate assets from political extraction. Journal of Law, Economics, and Organization, 29(2), 332-354.

Chaney, P. K., Faccio, M., \& Parsley, D. (2011). The quality of accounting information in politically connected firms. Journal of Accounting and Economics, 51(1), 58-76.

Chen, Y.-R. (2008). Corporate governance and cash holdings: Listed new economy versus old economy firms. Corporate Governance: An International Review, 16(5), 430-442.

Chen, Y.-R., \& Chuang, W.-T. (2009). Alignment or entrenchment? Corporate governance and cash holdings in growing firms. Journal of Business Research, 62(11), 1200-1206.

Claessens, S., Djankov, S., Fan, J. P., \& Lang, L. H. (2002). Disentangling the incentive and entrenchment effects of large shareholdings. The Journal of Finance, 57(6), 2741-2771.

Claessens, S., Feijen, E., \& Laeven, L. (2008). Political connections and preferential access to finance: The role of campaign contributions. Journal of Financial Economics, 88(3), 554-580.

Conger, J. A., Finegold, D., \& Lawler, E. E. (1998). Appraising boardroom performance. Harvard Business 
Review, 76, 136-164.

D’Espallier, B., Huybrechts, J., \& Schoubben, F. (2013). Why do firms save cash from cash flows? evidence from firm-level estimation of cash-cash flow sensitivities. Accounting $\mathcal{E}$ Finance, 54(4), 1125-1156.

Dalton, D. R., Daily, C. M., Johnson, J. L., \& Ellstrand, A. E. (1999). Number of directors and financial performance: A meta-analysis. Academy of Management Journal, 42(6), 674-686.

Ding, S., Jia, C., Wu, Z., \& Zhang, X. (2014). Executive political connections and firm performance: Comparative evidence from privately-controlled and state-owned enterprises. International Review of Financial Analysis, 36, 153-167.

Dittmar, A., Mahrt-Smith, J., \& Servaes, H. (2003). International corporate governance and corporate cash holdings. The Journal of Financial and Quantitative Analysis, 38(1), 111-133.

Dowling, M., \& Aribi, Z. A. (2013). Female directors and UK company acquisitiveness. International Review of Financial Analysis, 29, 79-86.

Estes, R. M. (1980). Corporate governance in the courts. Harvard Business Review, 58, 50-58.

Faccio, M. (2006). Politically connected Irms. The American Economic Review, 96, 369-386.

Fama, E. F., \& Jensen, M. C. (1983). Separation of ownership and control. Journal of Law and Economics, 26(2) 301-325.

Fee, C. E., \& Hadlock, C. J. (2004). Management turnover across the corporate hierarchy. Journal of Accounting and Economics, 37(1), 3-38.

Feng, X., \& Johansson, A. C. (2014). Escaping political extraction: Political participation, institutions, and cash holdings in China. China Economic Review, 30(0), 98-112.

Ferreira, M. A., \& Vilela, A. S. (2004). Why do firms hold cash? Evidence from EMU countries. European Financial Management, 10(2), 295-319.

Goldman, E., Rocholl, J., \& So, J. (2013). Politically connected boards of directors and the allocation of procurement contracts. Review of Finance, 17(5), 1617-1648.

Gujarati, D. N. (2009). Basic econometrics: Tata McGraw-Hill Education.

Hamzah, A. H., \& Zulkafli, A. H. (2014). Multiple shareholders structure (MSS) and corporate financial policy. Journal of Finance and Bank Management, 2(1), 107-134.

Haniffa, R., \& Hudaib, M. (2006). Corporate governance structure and performance of Malaysian listed companies. Journal of Business Finance $\mathcal{E}$ Accounting, 33(7ロ8), 1034-1062.

Harford, J., Mansi, S. A., \& Maxwell, W. F. (2008). Corporate governance and firm cash holdings in the US. Journal of Financial Economics, 87(3), 535-555.

Harris, M., \& Raviv, A. (2008). A theory of board control and size. Review of Financial Studies, 21(4), 
$1797-1832$.

Hermalin, B. E., \& Weisbach, M. S. (2003). Boards of directors as an endogenously determined institution: A survey of the economic literature. Economic Policy Review, 9(1), 7-26.

Hill, M., Fuller, K., Kelly, G. W., \& Washam, J. (2014). Corporate cash holdings and political connections. Review of Quantitative Finance and Accounting, 42(1), 123-142.

Jackling, B., \& Johl, S. (2009). Board structure and firm performance: Evidence from India's top companies. Corporate Governance: An International Review, 17(4), 492-509.

Jackowicz, K., Kozłowski, Ł., \& Mielcarz, P. (2014). Political connections and operational performance of non-financial firms: New evidence from Poland. Emerging Markets Review, 20, 109-135.

Jensen, M., C. (1986). Agency cost of free cash flow, corporate finance, and takeovers. Corporate Finance, and Takeovers. American Economic Review, 76(2), 323-329.

Jensen, M. C. (1993). The modern industrial revolution, exit, and the failure of internal control systems. The Journal of Finance, 48(3), 831-880.

Jensen, M. C., \& Meckling, W. H. (1976). Theory of the firm: Managerial behavior, agency costs and ownership structure. Journal of Financial Economics, 3(4), 305-360.

Johannisson, B., \& Huse, M. (2000). Recruiting outside board members in the small family business: An ideological challenge. Entrepreneurship $\mathcal{E}$ Regional Development, 12(4), 353-378.

Keynes, J. M. (1936). General theory of money, interest and employment. London: MacMillan.

Khwaja, A., \& Mian, A. (2005). Do lenders favor politically connected firms? Rent provision in an emerging financial market. The Quarterly Journal of Economics, 120, 1371-1411.

Kuan, T.-H., Li, C.-S., \& Chu, S.-H. (2011). Cash holdings and corporate governance in family-controlled firms. Journal of Business Research, 64(7), 757-764.

Kuan, T.-H., Li, C.-S., \& Liu, C.-C. (2012). Corporate governance and cash holdings: A quantile regression approach. International Review of Economics $\mathcal{E}$ Finance, 24(0), 303-314.

Kusnadi, Y. (2011). Do corporate governance mechanisms matter for cash holdings and firm value? Pacific-Basin Finance Journal, 19(5), 554-570.

Lasfer, M. (2002). Board structure and agency costs. Paper presented at the EFMA 2002 London Meetings.

Lee, K.-W., \& Lee, C.-F. (2009). Cash holdings, corporate governance structure and firm valuation. Review of Pacific Basin Financial Markets and Policies, 12(03), 475-508.

Levin, I. P., Snyder, M. A., \& Chapman, D. P. (1988). The interaction of experiential and situational factors and gender in a simulated risky decision-making task. The Journal of Psychology, 122(2), 173-181.

Lipton, M., \& Lorsch, J. W. (1992). A modest proposal for improved corporate governance. The Business 
Lawyer, 48(1) 59-77.

Loukil, N., \& Yousfi, O. (2016). Does gender diversity on corporate boards increase risk-taking? Canadian Journal of Administrative Sciences / Revue Canadienne des Sciences de l'Administration, 33(1), 66-81.

Masood, A., \& Shah, A. (2014). Corporate governance and cash holdings in listed non-financial firms of Pakistan. Business Review, 9(2), 48-72.

Masulis, R. W., \& Mobbs, S. (2011). Are all inside directors the same? Evidence from the external directorship market. The Journal of Finance, 66(3), 823-872.

Myers, S. C., \& Majluf, N. S. (1984). Corporate financing and investment decisions when firms have information that investors do not have. Journal of Financial Economics, 13(2), 187-221.

Opler, T., Pinkowitz, L., Stulz, R., \& Williamson, R. (1999). The determinants and implications of corporate cash holdings. Journal of Financial Economics, 52(1), 3-46.

Ozkan, A., \& Ozkan, N. (2004). Corporate cash holdings: An empirical investigation of UK companies. Journal of Banking $\mathcal{E}$ Finance, 28(9), 2103-2134.

Pathan, S., Skully, M., \& Wickramanayake, J. (2007). Board size, independence and performance: An analysis of Thai banks. Asia-Pacific Financial Markets, 14(3), 211-227.

Pinkowitz, L., stulz, R., \& Williamson, R. (2006). Does the contribution of corporate cash holdings and dividends to firm value depend on governance? A cross-country analysis. The Journal of Finance, 61(6), 2725-2751.

Raheja, C. G. (2005). Determinants of board size and composition: A theory of corporate boards. Journal of Financial and Quantitative Analysis, 40(02), 283-306.

Roberts, M. R., \& Whited, T. M. (2012). Endogeneity in empirical corporate finance. Unpublished working paper, University of Rochester.

Saeed, A., Belghitar, Y., \& Clark, E. (2014). Theoretical motives of corporate cash holdings and political connections: firms level evidence from a developing economy. International Review of Applied Economics, 1-19.

Sethi, P., Cunningham, B., \& Swanson, C. (1979). The catch-22 in reform proposals for restructuring, corporate boards. Management Review, 68(1), 27-28.

Shah, A., (2011). The corporate cash holdings: determinants and implications African Journal of Business Management, 5(34), 12939-12950.

Shen, C.-H., Lin, C.Y., \& Wang, Y.-C. (2015). Do strong corporate governance firms still require political connection, and vice versa? International Review of Economics $\mathcal{E}$ Finance, 39, 107-120.

Smith, N., Smith, V., \& Verner, M. (2006). Do women in top management affect firm performance? A panel study of 2,500 Danish firms. International Journal of productivity and Performance management, 
55(7), 569-593.

Steijvers, T., \& Niskanen, M. (2013). The determinants of cash holdings in private family firms. Accounting E Finance, 53(2), 537-560.

Stulz, R. (1990). Managerial discretion and optimal financing policies. Journal of Financial Economics, 26(1), 3-27.

Sun, Z., \& Wang, Y. (2016). Does ownership structure matter? Evidence from firms' excess cash in China. The European Journal of Finance, 22(4-6), 463-483.

Vafeas, N. (1999). Board meeting frequency and firm performance. Journal of Financial Economics, 53(1), 113-142.

Van Uytbergen, S., \& Schoubben, F. (2015). The effect of gender diversity on corporate cash policy. Paper presented at the annual conference on European Financial Management, edition:24, Amsterdam, The Netherlands.

Wasserman, J. (1988). Impact of venture capital on high-tech industries. Review of Business, 10(1), 5-6.

Wasserman, N. (2003). Founder-CEO succession and the paradox of entrepreneurial success. Organization Science, 14(2), 149-172.

Wintoki, M. B., Linck, J. S., \& Netter, J. M. (2012). Endogeneity and the dynamics of internal corporate governance. Journal of Financial Economics, 105(3), 581-606.

Wu, W., Wu, C., Zhou, C., \& Wu, J. (2012). Political connections, tax benefits and firm performance: Evidence from China. Journal of Accounting and Public Policy, 31(3), 277-300.

Xie, B., Davidson, W. N., \& DaDalt, P. J. (2003). Earnings management and corporate governance: the role of the board and the audit committee. Journal of Corporate Finance, 9(3), 295-316.

Yammeesri, J., \& Kanthi Herath, S. (2010). Board characteristics and corporate value: evidence from Thailand. Corporate Governance: The international journal of business in society, 10(3), 279-292.

Yeh, Y.-H., Shu, P.-G., \& Chiu, S.-B. (2013). Political connections, corporate governance and preferential bank loans. Pacific-Basin Finance Journal, 21(1), 1079-1101.

Yermack, D. (1996). Higher market valuation of companies with a small board of directors. Journal of Financial Economics, 40(2), 185-211.

You, J., \& Du, G. (2012). Are political connections a blessing or a curse? Evidence from CEO turnover in China. Corporate Governance: An International Review, 20(2), 179-194.

Zhang, Y., Zhou, J., \& Zhou, N. (2007). Audit committee quality, auditor independence, and internal control weaknesses. Journal of Accounting and Public Policy, 26(3), 300-327. 